\title{
Pengaruh Amitriptyline Dosis Lethal pada Bangkai Tikus Rattus Norvegicus strain Wistar terhadap Pertumbuhan Larva Musca Sp.
}

\section{The Effect of Lethal Dosage Amitriptyline in Dead Rat Rattus Norvegicus strain Wistar in Preventing of Larvae Musca Sp. Growth}

\author{
Puji Rahman ${ }^{1}$, Aswin Djoko $B^{2}$, Wening Prastowo ${ }^{3}$ \\ ${ }^{1}$ Program Studi Pendidikan Dokter Universitas Brawijaya \\ ${ }^{2}$ Laboratorium Parasitologi Fakultas Kedokteran Universitas Brawijaya \\ ${ }^{3}$ Laboratorium Kedokteran Forensik Rumah Sakit Umum Dr. Saiful Anwar Malang
}

\begin{abstract}
ABSTRAK
Peran Post Mortem Interval (PMI) sangat penting untuk memperkirakan waktu kematian yang dapat diketahui dengan menentukan umur larva lalat yang terdapat pada jenazah. Pertumbuhan larva lalat sangat dipengaruhi oleh suhu lingkungan, makanan, kelembapan, intensitas cahaya, dan kontaminan. Keberadaan obat antidepresan dapat mengacaukan estimasi waktu kematian hingga 77 jam. Penelitian ini merupakan penelitian eksperimental menggunakan media dua bangkai tikus. Tikus pertama dibunuh dengan cara diberikan amitriptyline $100 \mathrm{mg}$ peroral (LD50 = 350 $\mathrm{mg} / \mathrm{kgBB}$ ). Tikus kedua dibunuh dengan cara dislokasi cervical. Kedua bangkai ini dimasukkan ke 2 kandang yang telah berisi masing-masing 50 lalat Musca sp. Dilakukan pengamatan setiap 12 jam mulai dari larva lalat stadium satu sampai lalat dewasa. Setiap media tumbuh diambil 10 larva secara acak setiap hari untuk diukur panjang dan berat serta durasi pertumbuhannya. Hasil penelitian menunjukkan bahwa pertumbuhan larva pada media dengan kandungan amitriptyline berbeda secara signifikan dibandingkan pertumbuhan larva pada media tanpa kandungan amitriptyline. Panjang larva pada media tumbuh dengan kandungan amitriptyline lebih panjang, berat larva pada media tumbuh dengan kandungan amitriptyline lebih berat dan durasi pencapaian stadium lebih lambat sejak hari ke-3a $(p<0,005)$. Hasil penelitian ini menunjukkan bahwa amitriptyline dapat memperlambat pertumbuhan larva lalat Muscasp.
\end{abstract}

Kata Kunci: Amitriptyline, Musca sp., pertumbuhan larva

\section{ABSTRACT}

Insect evidence on the corpses can be used to estimate the Post Mortem Interval, however many factors including drugs may affect the rate of fly larva growth. Two rats were used in this experimental study in order to analyze the influence of amitriptyline on growth rate of fly larvae. One rat were given $100 \mathrm{mg}$ of amitriptyline orally (LD50 = 350mg/KgBW), and the other were killed by cervical dislocation and used as control. The rats were then simultaneously killed and caged individually into Musca sp. cages to let the flies deposit their eggs on the rat corpses. Ten developing larvae were sampled twice daily to determine the body length, weight and the growth rate until they were emerging to be adult. Result of this study showed that the length and the weight were significantly greater and the growths of Musca sp larvae in rat corpses containing amitriptyline were significantly slower than control since day $3 a(p<0,05)$. The fly larvae on rat corpses containing amitriptyline were significantly slower to develop to be pupa and adult. This result suggested that amitriptyline can decelerate the growth rate of fly larvae.

Keywords: Amitriptyline, growth of larva, Muscasp.

Jurnal Kedokteran Brawijaya, Vol. 26, No.2, Agustus 2010; Korespondensi: Puji Rahman. Program Studi Pendidikan Dokter Universitas Brawijaya, Jl. Veteran Malang Tel. (0341) 569117Email:drpujirahman.aj@gmail.com 


\section{PENDAHULUAN}

Untuk penyelidikan kematian yang tidak wajar diperlukan perkiraan waktu kematian (1). Salah satu prosedur tetap dalam identifikasi jenazah adalah dengan mengirimkan larva serangga yang ditemukan ke laboratorium parasitologi untuk mengetahui berapa umur larva sebagai penunjang dalam perkiraan waktu kematian (2). Perkiraan waktu kematian dari hasil investigasi dengan bantuan serangga dapat ditentukan Post Mortem Interval (3).

Pada kasus-kasus forensik di Malang, ternyata penemuan larva serangga mengerucut pada empat spesies dari ordo Diptera, terutama species yang dapat menimbulkan myasis seperti Chrysomia, Lucillia, Musca, dan Sarcophaga (4). Musca sp. merupakan lalat pertama yang datang pada jenazah dan segera meletakkan telurnya (5).

Amitriptyline adalah bahan kontaminan yang diduga dapat mempengaruhi pertumbuhan larva. Hasil observasi Survjit cheeta dkk tentang kematian yang berhubungan dengan obat di Inggris dan Wales, menemukan 468 kasus (11, $6 \%$ ) disebabkan karena penggunaan obat antidepresi (6). Masih terdapat pertanyaan apakah amitriptyline akan memperlambat pertumbuhan siklus larva lalat Musca sp. Pada suatu penelitian yang dilakukan oleh Duke dilaporkan kandungan amitriptyline akan memperlambat pertumbuhan larva (7).

\section{METODE}

Penelitian eksperimental ini menggunakan sampel sebanyak 10 ekor larva Musca sp. di masing-masing waktu pengukuran dari media tumbuh dengan dan tanpa kandungan amitriptyline untuk diukur panjangnya, ditimbang beratnya, serta dihitung durasi pertumbuhannya. Seratus ekor lalat Musca sp. yang ditangkap dari lingkungan Universitas Brawijaya, dimasukkan ke dalam dua buah kandang yang telah disediakan. Satu kandang diisi dengan bangkai tikus yang mati karena amitriptyline dengan cara disonde dan satu kandang yang lain diisi dengan bangkai tikus yang mati akibat dislokasi cervical. Pada penelitian ini, berat ratarata tikus sebesar $200 \mathrm{mg}$. LD50 amitriptyline untuk tikus adalah $350 \mathrm{mg} / \mathrm{kg} 8$ sehingga diberikan 100mg amitriptyline. Kedua bangkai tikus tersebut dibuat irisan pada garis tengah tubuh bagian ventral sepanjang leher sampai dekat anus sampai tampak organ dalam tubuh tikus. Kedua kandang diletakkan dalam ruangan dimana suhunya berkisar antara $23^{\circ} \mathrm{C}-26^{\circ} \mathrm{C}$. Dilakukan pemeriksaan setiap 12 jam yaitu pukul 05.00-07.00 dan 17.00-18.00.

\section{HASIL}

\section{Perbedaan Panjang Larva pada Media Dengan dan Tanpa} Kandungan Amitriptyline

Gambar 1 menunjukkan perbandingan rata-rata panjang larva Musca sp. yang tumbuh pada media dengan dan tanpa kandungan amitriptyline yang diukur setiap 12 jam. Pengamatan dilaksanakan mulai dari hari ke (0) hingga semua larva berubah menjadi pupa, lalu berkembang menjadi lalat dewasa. Sejak hari ke 3 pagi sudah terlihat perbedaan yang signifikan antara larva yang tumbuh pada media dengan kandungan amitriptyline $(5,5 \mathrm{~mm})$ dibandingkan dengan larva yang tumbuh pada media tanpa kandungan amitriptyline yaitu 4,1 mm ( $p=0.001)$.

Hasil menunjukkan bahwa keberadaan amitriptyline dalam media hidup lalat mempengaruhi panjang larva lalat Musca sp. secara signifikan. Pada hari ke-1 sore didapatkan panjang larva stadium 1 masih sama panjang antara larva yang tumbuh pada media dengan kandungan amitriptyline dan tanpa kandungan amitriptyline yaitu 1 $\mathrm{mm}$. Pada hari ke 2 (baik pengamatan pagi dan sore) didapatkan larva stadium dua belum berbeda signifikan antara larva yang tumbuh pada media dengan kandungan amitriptyline dan tanpa kandungan amitriptyline yaitu masing-masing sebesar masing-masing $2.8 \mathrm{~mm}$ dan 2.1 (pagi) dan $4.5 \mathrm{~mm}$ dan $3.5 \mathrm{~mm}$ (sore). Hasil uji statistik menunjukkan tidak ada perbedaan berat signifikan pada hari ke-2 memperlihatkan bahwa saat telur Musca sp. menetas menjadi larva stadium 2 belum dipengaruhi oleh kandungan media tumbuh. Hal ini dapat dimengerti karena saat pengukuran hari ke-2 larva tersebut baru saja menyesuaikan dengan media tumbuh.

Pada hari ke-3 pagi didapatkan hasil pengukuran panjang L3 pada media tumbuh dengan kandungan amitriptyline sebesar $5.5 \mathrm{~mm}$, sedangkan pada media tumbuh tanpa kandungan amitriptyline sebesar 3,5 mm. Hal ini menunjukkan bahwa rata-rata panjang larva antara kedua media tumbuh berbeda secara signifikan sejak hari ke-3 pagi. Hasil ini menunjukkan bahwa kandungan amitriptyline mulai mempengaruhi pertumbuhan larva tersebut setelah larva mulai memakan media yang telah disediakan.

Pada pengamatan sore harinya, yaitu hari ke-3 sore didapatkan hasil pengukuran larva stadium 3 pada media tumbuh dengan kandungan amitriptyline sebesar $6,8 \mathrm{~mm}$, sedangkan pada media tumbuh tanpa kandungan amitriptyline sebesar 5,3 $\mathrm{mm} \quad(p=0.001)$. Mulai dari pengukuran hari ke-4 pagi dan seterusnya ternyata didapatkan panjang larva yang tumbuh pada media dengan kandungan amitriptyline berbeda secara signifikan dibandingkan panjang larva yang tumbuh pada media tanpa kandungan amitriptyline. Hal ini juga ditunjukkan dengan panjang larva pada media tumbuh dengan kandungan amitriptyline dapat mencapai puncak panjang rata-rata $14,9 \mathrm{~mm}$ pada hari ke-10 pagi, sedangkan panjang larva lalat pada media tumbuh tanpa kandungan amitriptyline mencapai puncak panjang rata-rata $12,9 \mathrm{~mm}$ pada hari ke-9 sore. Apabila dibandingkan dengan literatur yang ada, panjang larva stadium 3 yang tumbuh pada media dengan kandungan amitriptyline lebih panjang dibandingkan panjang normal yaitu antara 5,5-14,9 mm, sedangkan normal panjang larva stadium 3 hanya 7-12 $\mathrm{mm}$. Pada stadium pupa, panjang pupa yang berasal dari larva yang tumbuh pada media dengan kandungan amitriptyline mencapai $8,7 \mathrm{~mm}$, lebih panjang dibandingkan pupa yang berasal dari larva yang tumbuh pada media tanpa kandungan amitriptyline yang hanya mencapai 6,9 mm, sedangkan berdasar literatur panjang pupa normal adalah kurang lebih $8 \mathrm{~mm}$. Dapat disimpulkan bahwa keberadaan amitriptyline dalam media hidup lalat secara signifikan mempengaruhi panjang larva lalat pada 


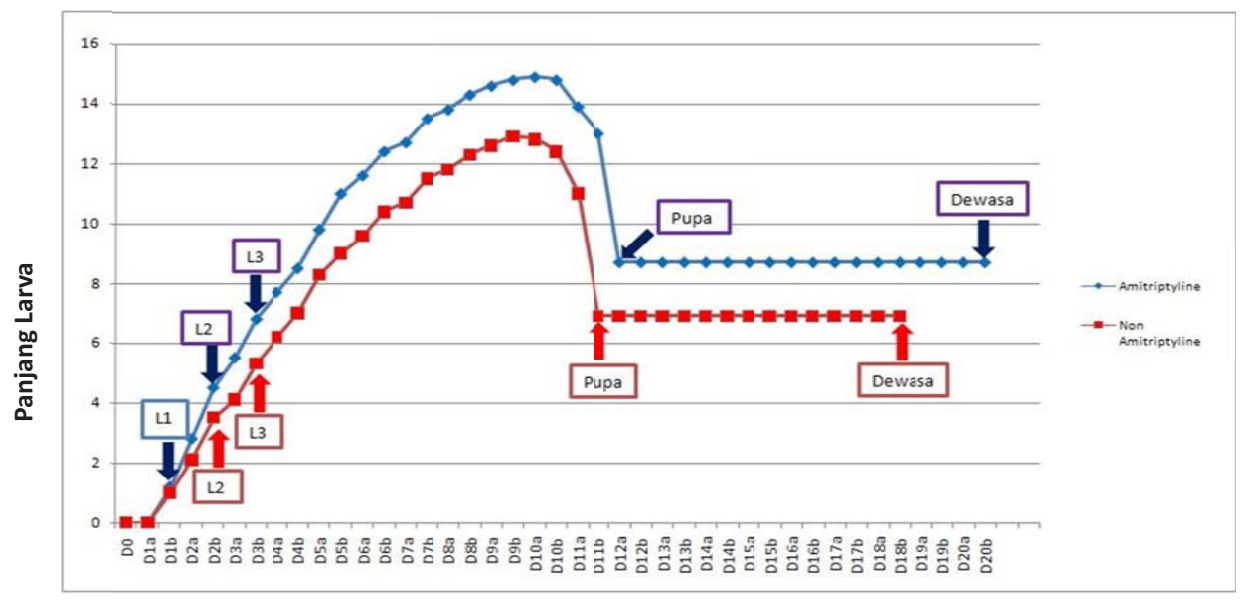

Hari dan Pengamatan

Gambar 1. Grafik panjang larva lalat Musca sp.

\section{Keterangan:}

a) pengamatan pagi hari $05.00-06.00$

b) pengamatan sore hari $17.00-18.00$

larva stadium tiga dan pupa (8).

Gambar 1 menunjukkan bahwa pertumbuhan panjang larva pada media dengan kandungan amitriptyline, mampu mencapai puncak rata-rata panjang $14,9 \mathrm{~mm}$ pada hari ke-10 pagi, kemudian menjadi pupa dengan panjang rata-rata $8,7 \mathrm{~mm}$ pada hari ke12 pagi. Larva pada media tanpa kandungan amitriptyline hanya mencapai puncak rata-rata panjang $12,9 \mathrm{~mm}$ pada hari ke-9 sore, kemudian menjadi pupa dengan panjang rata-rata $6,9 \mathrm{~mm}$ pada hari ke-11 sore.

Perbedaan Berat Larva pada Media Dengan dan Tanpa Kandungan Amitriptyline

Gambar 2 menunjukkan perbandingan rata-rata berat larva Musca sp. pada media tumbuh dengan dan tanpa kandungan amitriptyline. Pengukuran berat dimulai pada hari keempat (4a) pagi hari. Hal ini disebabkan karena pada hari ke-nol (0) sampai hari ketiga sore hari (3b), larva masih terlalu kecil untuk dilakukan pengukuran berat. Pengamatan dilakukan sampai larva menjadi pupa, lalu berkembang menjadi lalat dewasa. Perbedaan berat yang signifikan sudah mulai tampak sejak pertama kali dilakukan pengukuran yaitu pada hari keempat pagi hari (4a) 4,88 mg pada larva yang tumbuh pada media dengan kandungan amitriptyline berbanding 2,9 mg pada larva yang tumbuh pada media tanpa kandungan amitriptyline.

Dari Gambar 2 dapat dilihat bahwa pada pengukuran berat pertama kali yaitu pada hari ke-4 (pengamatan pagi hari) didapatkan hasil penimbangan larva stadium 3 pada media dengan kandungan amitriptyline sebesar 4,88 $\mathrm{mg}$, sedangkan pada media tanpa kandungan amitriptyline sebesar 2,90 mg. Hal ini menunjukkan bahwa rata-rata

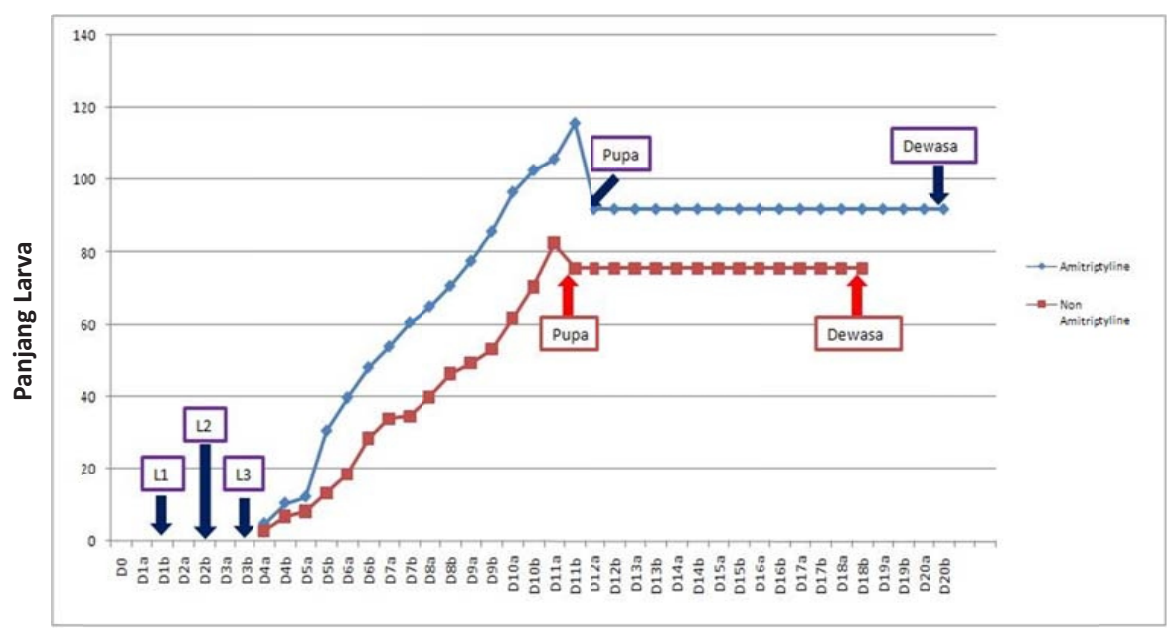

Hari dan Pengamatan

Gambar 2. Grafikberat larva lalat Muscasp.

\section{Keterangan:}

a) pengamatan pagi hari $05.00-06.00$

b) pengamatan sore hari $17.00-18.00$ 
berat larva yang dibandingkan mulai berbeda signifikan sejak pertama kali dilakukan penimbangan pada hari ke-4 pagi dan seterusnya. Mulai dari pengukuran hari ke-4 pagi dan seterusnya ternyata bahwa berat larva yang tumbuh pada media dengan kandungan amitriptyline berbeda secara signifikan dibandingkan berat larva yang tumbuh pada media tanpa kandungan amitriptyline. Hal ini juga ditunjukkan dengan panjang larva pada media tumbuh dengan kandungan amitrptyline dapat mencapai puncak berat rata-rata $115, \mathrm{i} 68 \mathrm{mg}$ pada hari ke-11 sore, sedangkan berat larva lalat pada media tumbuh tanpa kandungan amitriptyline mencapai puncak berat rata-rata $82,46 \mathrm{mg}$ pada hari ke-11 pagi. Pada stadium pupa, ternyata berat pupa yang berasal dari larva yang tumbuh pada media dengan kandungan amitriptyline mencapai $91,78 \mathrm{mg}$, lebih berat dibandingkan pupa yang berasal dari larva yang tumbuh pada media tanpa kandungan amitriptyline yang hanya mencapai $75,63 \mathrm{mg}$. Dapat disimpulkan bahwa keberadaan amitriptyline dalam media hidup lalat secara signifikan mempengaruhi berat larva lalat pada larva stadium ketiga dan pupa.

Gambar 2 menunjukkan bahwa pertumbuhan larva pada media dengan kandungan amitriptyline mampu mencapai puncak rata-rata berat $115,68 \mathrm{mg}$ pada hari ke-11 sore, kemudian menjadi pupa pada hari ke-12 pagi dengan berat rata-rata 91,78 mg. Pertumbuhan larva pada media tanpa kandungan amitriptyline mampu mencapai puncak rata-rata berat $82,46 \mathrm{mg}$ pada hari ke-11 pagi, kemudian menjadi pupa pada hari ke-11 sore dengan berat rata-rata $75,63 \mathrm{mg}$.

Perbedaan Durasi Pertumbuhan Larva pada Media
Dengandan Tanpa Kandungan Amitriptyline

Dari Gambar 1 dapat dilihat bahwa pertumbuhan larva pada media dengan kandungan amitriptyline, pencapaian stadiumnya lebih lambat dibandingkan dengan larva pada media tanpa amitriptyline. Durasi pertumbuhan larva stadium 1 dan larva stadium 2 pada masing-masing media ternyata tidak berbeda yaitu masing-masing 1 hari. Durasi pertumbuhan larva stadium 3 pada media dengan kandungan amitriptyline berlangsung 9 hari, sedangkan pada media tanpa kandungan amitriptyline ternyata berlangsung lebih cepat yaitu 8,5 hari.

Pertumbuhan pupa untuk mencapai dewasa pada media dengan kandungan amitriptyline berdurasi 9 hari, sedangkan pada media tanpa kandungan amitriptyline berlangsung lebih cepat yaitu 7,5 hari. Total durasi yang dibutuhkan mulai dari larva stadium satu hingga dewasa pada media tumbuh dengan kandungan amitriptyline adalah 20 hari, sedangkan pada media tumbuh tanpa kandungan amitriptyline berlangsung lebih cepat yaitu 18 hari.

\section{DISKUSI}

Pertumbuhan larva lalat dalam siklus kehidupan metamorfosisnya sangat bergantung pada media hidupnya. Kandungan amitriptyline pada media hidup larva lalat diduga akan memperlambat pada proses pertumbuhannya. Dalam penelitian yang telah dilakukan oleh Duke, 2002, akan pengaruh amitriptyline dan nortriptyline terhadap estimasi waktu kematian dengan menggunakan perkembangan serangga, didapatkan bahwa hasil pemberian amitriptyline pada media tumbuh larva akan menghasilkan larva Sarcophaga bullata yang lebih panjang. Pada penelitian ini ternyata didapatkan larva Musca sp. pada media dengan kandungan amitriptyline tumbuh dengan panjang yang berbeda secara signifikan dibandingkan larva pada media tanpa kandungan amitriptyline (7).

Pertumbuhan larva lalat pada media dengan kandungan amitriptyline juga tumbuh dengan durasi yang berbeda secara signifikan dibandingkan larva lalat pada media tanpa kandungan amitriptyline. Pada larva stadium satu dan larva stadium dua belum terdapat perbedaan durasi waktu antara larva yang tumbuh pada media dengan dan tanpa kandungan amitriptyline. Masing-masing stadium pada masing-masing media tumbuh sama durasinya yaitu 24 jam (1 hari). Pada penelitian ini, durasi larva stadium tiga (L3) yang tumbuh pada media dengan kandungan amitriptyline tidak terlalu berbeda jauh dengan tanpa kandungan amitriptyline. Untuk larva stadium tiga yang tumbuh dengan media amitirptyline ternyata lebih lambat yaitu berlangsung 216 jam (9 hari), sedangkan dengan durasi larva stadium tiga yang tumbuh pada media tanpa kandungan amitriptyline berlangsung lebih cepat beberapa jam yaitu 204 jam (8,5 hari). Apabila dibandingkan dengan literatur yang ada, durasi normal larva stadium 3 kurang lebih $4-13$ hari pada suhu $35-38^{\circ} \mathrm{C}$ dan membutuhkan waktu $14-30$ hari pada suhu $12-17^{\circ} \mathrm{C}$. Perkembangan larva hingga stadium tiga dapat dicapai dalam 5-14 hari. Pada penelitian ini suhu ruangan rata-rata mencapai $22-28^{\circ} \mathrm{C}(8,9)$.

Pada durasi stadium pupa untuk dapat menjadi dewasa, pupa yang berasal dari media tumbuh dengan kandungan amitriptyline berlangsung lebih lama yaitu 216 jam (9 hari), sedangkan pupa yang berasal dari media tumbuh tanpa amitriptyline berlangsung lebih cepat yaitu 180 jam (7,5 hari). Apabila dibandingkan dengan literatur yang ada, durasi stadium pupa berlangsung 2-6 hari pada suhu 32$37^{\circ} \mathrm{C}$, namun membutuhkan $17-24$ hari pada suhu $14^{\circ} \mathrm{C}$, menurut literatur lain stadium pupa akan berlangsung selama 3-10 hari. Pada penelitian ini suhu ruangan ratarata mencapai $22-28^{\circ} \mathrm{C}(8,9)$.

Total durasi untuk mencapai dewasa pada larva yang tumbuh pada media dengan kandungan amitriptyline adalah 480 jam (20 hari) berbeda signifikan dibandingkan dengan larva yang tumbuh pada media tanpa kandungan amitriptyline yang membutuhkan waktu lebih lama yaitu 432 jam (18 hari). Hal ini sesuai dengan hasil penelitian yang dilakukan oleh Duke (2002) tentang pengaruh amitriptyline dalam memanjangkan waktu pertumbuhan Sarcophaga bullata (7).

Keberadaan bahan narkotika mampu mempercepat estimasi waktu kematian sampai 29 jam. Dari hasil penelitian dapat disimpulkan bahwa keberadaan amitriptyline dalam media hidup lalat secara signifikan memperlambat durasi pencapaian stadium larva lalat selama 48 jam (2 hari) (10).

Bila dikaitkan amitriptyline yang memiliki target reseptor di Sistem Saraf Pusat, maka dapat ditarik sebuah pemikiran, bahwa keberadaan amitriptyline memungkinkan untuk mempengaruhi produksi hormon ecdysone dan juvenile saat terjadinya moulting dan metamorfosis, sehingga dapat memberikan perbedaan durasi pertumbuhan pada larva lalat Musca sp. yang terpapar amitriptyline. Hal ini bisa dimungkinkan karena 
potensi dan selektivitas amitriptyline dalam ambilan kembali neurotransmitor di sistem saraf pusat. Pada manusia, dari beberapa jenis antidepresi trisiklik terdapat perbedaan potensi dan selektivitas hambatan ambilan kembali berbagai neurotransmitor. Ada yang sangat sensitif terhadap norepinefrin, ada yang sensitif terhadap serotonin, dan ada pula yang sensitif terhadap dopamin. Tidak jelas hubungan antara mekanisme penghambatan ambilan kembali katekolamin dengan antidepresinya (11).

Bila dianalogikan dalam proses metamorfosis lalat, terdapat dua hormon yang sangat berperan, yaitu ecdysone dan juvenile hormone $(\mathrm{JH})$. Titer yang tinggi untuk juvenile hormone dan ecdysone akan mensinyal larval-to-larval molt, sedangkan titer ecdysone yang tinggi dan juvenile hormone yang rendah akan mencetus metamorfosis. Dengan potensi dan selektivitasnya yang berbeda terhadap ecdysone dan juvenile hormone $(\mathrm{JH})$, amitriptyline dimungkinkan menyebabkan larva dan pupa Musca $s p$. pada media amitriptyline lebih panjang dan berat dari pada media tanpa amitriptyline tetapi dengan durasi yang lebih lama. Kesimpulan ini perlu dibuktikan dengan penelitian lebih lanjut tentang ambilan kembali hormon mana yang lebih dipengaruhi oleh amitriptyline

\section{DAFTAR PUSTAKA}

1. Satriyo D. Permasalahan Narkoba di Indonesia dan Penanggulangannya. (Online) 2003. http:// www.solusihukum.com/news/arsip/narkoba.pdf [diakses 30 Nopember 2007].

2. Anderson GS. The Use of Insects in Death Investigations: An Analysis of Forensic Entomology Cases in British Columbia over a Five Year Period. Canadian Society of Forensic Science Journal. 1995; 28(4):277-92.

3. Goff ML. Estimation of The Postmortem Interval Using Arthropoda Development and Successional Patterns. Forensic Science Review. 1993; 5: 81-94.

4. Baskoro AD. Larva Lalat yang Ditemukan Pada Jenazah Tanpa Identitas di Malang. [Unpublished]. Universitas Brawijaya, Malang. 2000-2007.

5. Frost $\mathrm{CL}$, Braig HR, Amendt J, and Perotti MA. Indoor Arthropods of Forensic Importance: Insects Associated with Indoor Decomposition and Mites as Indoor Markers. In: Amendt J, Goff ML, Campobasso $\mathrm{CP}$, and Grassberger M. Current Concepts in Forensic Entomology. New York: Springer; 2010; pp. 93-108.

6. Cheeta S, Schifano F, Oyefeso A, Webb L, and Ghodse $\mathrm{AH}$. Antidepressant-Related Deaths and Antidepressant Prescriptions in England and Wales, 1998-2000. The British Journal of Psychiatry. 2004; 184: 41-47.

7. Duke NC. Sustained High Levels Of Foliar Herbivory of the Mangrove Rhizophora Stylosa by a Moth Larva Doratifera Stenosa (Limacodidae) in North-Eastern
(12).

Dengan melaksanakan prosedur perhitungan usia serangga ini, maka dapat diketahui waktu dari sejak kematian terjadi pada manusia ataupun hewan sampai ditemukannya jenazah manusia atau hewan tersebut oleh manusia, atau disebut Post Mortem Interval (PMI) (Goff, 1993). PMI inilah yang kemudian digunakan dalam membantu investigasi penyidik. Pada kasus dengan ditemukannya jenazah dengan sebab kematian akibat overdosis penyalahgunaan obat, salah satunya amitriptyline maka siklus hidup larva yang ditemukan pada tubuh jenazah juga akan berubah. Dalam penelitian ini amitriptyline ternyata dapat membuat durasi siklus hidup lalat Musca sp. mengalami perlambatan. Jika setelah pemeriksaan toksikologi didapatkan kemungkinan korban meninggal karena amitriptyline, maka panjang larva yang diperoleh harus dibandingkan dengan data pola pertumbuhan larva pada media amitriptyline untuk memperkirakan waktu kematiannya atau dengan melihat sisa waktu yang diperlukan oleh larva tersebut menjadi pupa dan lalat dewasa (13). Dapat disimpulkan bahwa amitriptyline dapat memperlambat pertumbuhan larva lalat Musca sp. baik dalam hal panjang, berat, serta durasi.

Australia. Wetlands Ecology and Management. 2002; 10(5): 403-419.

8. Monzon RB, Sanchez AR, Tadiaman BM, et al. A Comparison of the Role of Musca Domestica (Linnaeus) and Chrysomya Megacephala (Fabricius) as Mechanical Vectors of Helminthic Parasites in a Typical Slum Area of Metropolitan Manila. The Southeast Asian Journal of Tropical Medicine and Public Health. 1991; 22(2):222-228.

9. Singh GJP and Vardanis A. Chitinases in the House Fly, Musca Domestica: Pattern of Activity in the Lifecycle and Preliminary Characterization. Insect Biochemistry. 1984; 14(10): 215-218.

10. Gill JR. Practical Toxicology for the Forensic Pathologist. Forensic Pathology Reviews. 2005; 2(10): 243-269.

11. Sharif NA, Kelly CR, Crider JY, and Davis TL. Serotonin-2 (5-HT2) Receptor-Mediated Signal Transduction in Human Ciliary Muscle Cells: Role in Ocular Hypotension. Journal of Ocular Pharmacology and Therapeutics. 2006; 22(6): 389-401.

12. Cheeta S, Schifano F, Oyefeso A, Webb L, and Ghodse AH. Antidepressant-Related Deaths and Antidepressant Prescriptions in England and Wales, 1998-2000. The British Journal of Psychiatry. 2004; 184: $41-47$

13. Bourel B, Hédouin V Martin-Bouyer L, Bécart A, Tournel G, Deveaux M, and Gosset D. Effects of Morphine in Decomposing Bodies on the Development of Lucilia Sericata (Diptera: Calliphoridae). Journal of Forensic. 1999; 44(2): 354-358. 